\title{
RECENSIONES
}

\section{Luisa Pinzón \\ Varilla (2014) \\ Las aguas que contengo y me contienen \\ Bogotá. Editorial Santa Bárbara}

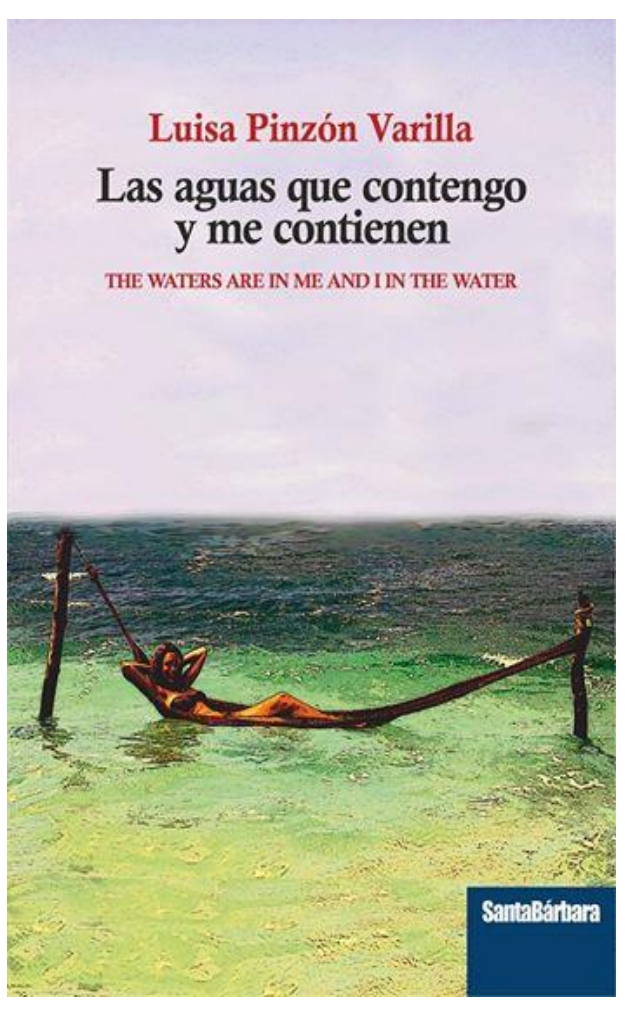

Las aguas que contengo y me contienen es un poemario del que brota la vida entre sus versos, del que el agua fluye por sus páginas, en el que la nueva esencia de la poesía americana se entremezcla con el más clásico espíritu de los versos llegados desde Grecia, España o Italia siglos atrás, o desde la misma América hace apenas un puñado de años. La naturaleza bulle, corre, nace, crece y vuelve sobre sí misma. El tiempo se apodera de las almas más sencillas y también de aquellas llamadas a perdurar por los siglos. Luisa Pinzón se asoma a la ventana de su hogar y desde ella alcanza con sus pupilas todos los tiempos de la mujer que vive el día a día, que sueña y que sufre, que es capaz de concentrar en su pecho toda la herencia de su sexo, toda la tradición de un pasado que está en los genes femeninos y que los proyecta desde su presente hacia un futuro lleno de esperanza, ese que nunca muere, y que tal vez nunca llegue.

Sueños, espejos, cascadas, luces, colores... inundan nuestros sentidos desde una naturaleza salvaje y paciente, sufrida y tenaz que crece y se atrapa a sí misma con torbellinos que la hacen morir y nacer, crecer y caer para reencontrarse a sí misma a cada instante desde la fuerza del agua en todas sus manifestaciones, como fuente inagotable, como mar que envuelve, como océano que nos hace perder la mirada, y con ella la vida, como ríos que fluyen entre montañas, conducidos hasta el mismo nacimiento que es, a la postre, su muerte.

Los amantes se reencuentran bajo la luz de una luna que platea sus cuerpos, que baña sus sentidos, que descubre los valles ahora cubiertos, tanto tiempo a la intemperie. Y la poetisa sufre los avatares de una existencia que la aboca hacia el reencuentro con un pasado que es algo más que el ayer, si él no está, cuando el presente deja de existir y él solo queda en el recuerdo, en un recuerdo al que acude cuando la luna llega tras dormir tanto tiempo en un barco de vela desde un Norte 
lejano. Macondo, la tierra, el aire, el agua, el objeto que es poseído porque así se entiende que debe ser, sin más freno que la animalidad de quien ejerce su poder, un triste poder que lo hunde cada vez más, que hace cada día más grande la capacidad de resistir, y triunfar al fin, algún día que está por llegar. El tiempo, como el viejo reloj de la torre de san Juan, ese señor que sin existir domina los cielos con sus estrellas, los cuerpos con sus impulsos, la carne con sus dueños y sus dueñas; el tiempo, marcado por las lluvias, los vientos y los suspiros que con ellos vuelan cada madrugada, cada amanecer, antes de que el día acabe de salir tras las montañas llenas de misterio. Y este misterio es el que encontramos entre cada línea, entre cada página de este libro que usted leerá con la parsimonia y el goce precisos para navegar entre sus versos. Su edición en español e inglés permite el acceso a esta obra a lectores que podrán disfrutar desde cualquiera de las dos lenguas de una poesía que sorprenderá por su capacidad de brotar desde la tierra.

Juan de Dios Villanueva Roa 